\title{
Mia Couto: justiça e vida nua em O Último Voo do Flamingo
}

\author{
Mia Couto: justice and bare life in The Last Flight of the Flamingo
}

José Paulo Cruz Pereira ${ }^{1}$

Enviado em: 21/08/2018

Aceito em: 07/12/2018

\begin{abstract}
Resumo: A minha leitura segue o desafio com que somos confrontados, como uma espécie de enigma, no início do romance: "os soldados [da ONU] morreram? Foram mortos?" Em busca de uma resposta, pondera aquelas questões que dizem respeito aos problemas da morte e da vida, tal como eles são colocados no mundo ficcional de Tizangara. Compre-ende-os, então, com base nas posições contidas em "Sobre uma crítica do poder como violência", de Walter Benjamin e nos pensamentos, quer de Emmanuel Lévinas, quer de Jacques Derrida. Reconsiderando, também, a bibliografia crítica existente sobre o romance de Mia Couto, ela oferece igualmente uma nova forma de entender as mortes de Tizangara, discernin-do, no discurso do padre Muhando e nos do círculo das suas amizades, Zeca Andorinho e Sulplício, os pressupostos transformados de uma certa leitura da bíblia que nos ajuda a entender a aleoria trágica do final do romance.
\end{abstract}

Palavras-chave: Justiça, lei, "vida nua”, alteridade, responsabilidade.

Abstract: My reading follows the challenge we are confronted with, as a sort of enigma, at the beginning of the novel: "did the [UN] soldiers die? Were they killed?". Looking for an answer, it ponders those issues of life and death, as they are posed by the fictive world of Tizangara. And it understands those concepts by taking into account not only Walter Benja-min's positions, in his Critique of Violence, but also the thoughts of both Emmanuel Lévinas and Jacques Derrida. Reviewing the existing critical bibliography on Mia Couto's novel as well, it offers an alternative way of understanding the death of the UN soldiers in Tizangara by capturing, in the speech of father Muhando and that of his closest friends, the wizard Zeca Andorinho and the old Suplício, certain transposed principles of the bible that also help us to understand the tragic alegory of the disapearance of the nation in the end of the novel.

Keywords: Justice, law, "bare life", alterity, responsability.

\section{Entre morrer e ser morto: «só os factos são sobrenaturais»...}

O Último Voo do Flamingo é, provavelmente, o mais lido e celebrado dos romances do escritor moçambicano Mia Couto. Mas talvez o mais enigmático tam-bém. Com efeito, a sua abertura faz-se por um curioso preâmbulo. Referindo-se, por um lado, à história narrada e, por outro, quer às circunstâncias da sua escrita, quer aos efeitos da sua recepção, aí se avança, no entanto, com um certo enigma. Como se formula ele?

\footnotetext{
${ }^{1}$ Docente de Literaturas Africanas de Língua Portugesa no Departamento de Artes e Humanidades da Universidade do Algarve.E-mail: jplmcpereira@gmail.com
} 
Tudo começou com eles, os capacetes azuis. Explodiram. Sim, é o que aconteceu a esses soldados. Simplesmente começaram a explodir. Hoje, um. Amanhã mais outro. Até somarem, todos descontados, a quantia de cinco falecidos. Agora, per-gunto: explodiram na inteira realidade? Diz-se, em falta de verbo. [...] Os soldados da paz morreram? Foram mortos? Deixo-vos na procura de uma resposta, ao longo destas páginas. (COUTO 2004, 11; sublinhado meu)

Eis, portanto, o desafio aí lançado ao leitor: «os soldados da paz morreram? Foram mortos?». Qualquer busca de uma resposta nos obrigaria, aqui, à ponde-ração de um certo limite. Esse limite diria respeito, por um lado, à língua - os soldados teriam «explodido», não «na inteira realidade», mas «em falta de verbo»... Mas, por outro lado, ele prender-se-ia, também, com esta insinuada dificuldade na distinção entre uma morte natural e outra cometida, ou exteriormente desencadeada. O quê / quem teria provocado essas explosões? Diversamente percorrido por cada das múltiplas leituras que tem suscitado, é possível verificar que todas elas convergem na constatação de que, como diria Phillip Rothwell, no seu Leituras de Mia Couto: aspectos de um pós-modernismo moçambicano: «O leitor nunca fica a saber o que aconteceu em Tizangara» $(2015,178)$. Pois, como observaria também Ana Mafalda Leite, em «As personagens-narrativa em Mia Couto, um exemplo para começar: o personagem-tradutor de mundos», em O Último Voo do Flamingo:

O tradutor organiza a narrativa através dos testemunhos dos personagens da aldeia - o feiticeiro Andorinho, o padre Muhando, a puta Ana Deusqueira, o [adjunto do] administrador Chupanga, a velha-jovem amante Temporina - como uma narra-tiva percorrido por veios de muitas cores. Os motivos que levaram às explosões dos capacetes azuis efabulam-se a muitas vozes, que desorientam a escrita do relator das Nações Unidas, Massimo. (2013, 170-171; sublinhado meu)

Ora, uma vez que Massimo Risi representa, também, a posição do leitor euro-peu que somos, o que se verifica é que:

Massimo vai de confusão em atordoamento, na impossibilidade de entender as falas narrativas, mesmo com tradutor. [...Pois] Tizangara, seus provérbios e ditos, seus personagens e 'contadeirices' em estado permanente de mito, desorientam Massimo e o leitor, surpresos, de capítulo em capítulo. (Ibidem, 171)

Ou ainda, como nota, também, Carmen Lúcia Tindó Secco, no seu «Entre crimes, detectives e mistérios (Pepetela e Mia Couto - riso, melancolia e o desven-damento da história pela ficção)»:

Não é a língua que Massimo Risi não compreende, mas os modos de sentir, ver e pensar daquela gente. A hiância entre mundos diversos permanece, assim como também fica sem explicação a causa das explosões. Os depoimentos e falas das personagens representativas das tradições culturais moçambicanas, ao invés de esclarecerem o investigador, o confundem ainda mais. (2011, 5; sublinhado meu)

Ora, é justamente a este propósito - o da «causa das explosões», ou o dos motivos que a elas conduzem... - que gostaríamos de situar a leitura a que aqui nos propomos. Acolhendo a presença dos soldados das Nações Unidas - cujas estra-nhas mortes determinarão a necessidade do inquérito que justificará a presença do relator italiano Massimo Risi, incumbido de ali apurar as causas de tais misteriosos falecimentos - Tizangara é, assim, o lugar de um mistério. Aberto - como seria de tradição - à presença, tanto dos seus antepassados já mortos, quanto dos seus deuses a aldeia expõe-se, ainda, à ameaçadora presença 
de outras entidades - tanto vindas de dentro do país, quanto de fora dele, ambas pertencentes ao reino dos vivos. A vulnerabilidade de um tal espaço fica, aliás, bem patente no que nos diz Zeca Andorinho, no depoimento que presta a Massimo Risi:

É que aqui, na vila, ninguém nos garante. Nem a terra, que é propriedade exclusiva dos deuses, nem a terra é poupada das ganâncias. Nada é nosso nos dias de agora. Chega um desses estrangeiros, nacional ou de fora, e nos arranca tudo de vez. Até o chão nos arrancam. [...] Por exemplo: há dias esse administrador Jonas [...]. Agora, eu recebo ordem de um Jonas? Aqui, em Tizangara? Ele é estrangeiro, tal igual o senhor. (COUTO 1987, 156; sublinhados meus).

De resto, também no desabafo que tem com o filho - precisamente o narra-dor-«tradutor de Tizangara» - a personagem do velho Sulplício - o exortará a que pense no que tais estrangeiros - uns de dentro: os «filhos estranhos» da pátria, aqueles que, pelo facto de a explorarem, dela fazem a sua «mina»... E outros de fora: os que, verdadeiramente, a minaram, fornecendo-lhe dispositivos para uma guerra com que podiam lucrar... - têm feito a Tizangara (e ao país):

- É que eu, assim, deixado e desleixado, me lembro a própria nossa terra. Porque a nossa pátria não via em si o apreço de seus filhos. [...] Fazia lembrar aquele homem que, de tanto ressuscitar, acabou morrendo. Eu que visse como haviam esburacado o nosso chão. Uns semeavam minas no país. Eram esses de fora. Ou-tros, de dentro, colocavam o país numa mina. - Sabe, filho, o que é pior? I -Eé o quê, pai? / - É que os nossos antepassados nos olham agora como filhos estra-nhos. (Ibidem, 210)

Sulplício compara-se, aqui, não apenas à sua própria terra, mas também a um Cristo. O mesmo Cristo que reaparecerá, aquando da prisão do padre Muhando - que «semelhava um Cristo negro, carregando uma invisível cruz» (Ibidem, 125). De resto, certos sinais se irão disseminando, ao longo do romance, que nos hão-de sugerir a possibilidade de antecipar a leitura que aqui trazemos, quanto à «causa da[quela]s explosões», que Carmen Lúcia Tindó Secco observa permanecerem por explicar. Para Sulplício - tal como para Zeca Andorinho, em boa verdade - o mal residia no facto de que «os novos-ricos se passeavam por um território de rapina, não tinham pátria. Sem amor pelos vivos, sem respeito pelos mortos» (Ibidem, 114). Como relacionar com este estado de coisas a explicação daquelas mortes que, implicando a desaparição dos soldados, terão, no entanto, lugar sem vestígíos outros que não os de seus sobrantes adereços - uma bota, uma bóina... - e um órgão genital masculino: um pénis decepado? Mortes cuja estranheza permanece, neste sentido, por qualificar e atribuir: morreram? Foram mortos? Atentemos, uma vez mais, nas palavras do tradutor de Tizangara:

Eles [os soldados da ONU], coitados, acreditavam ser donos de fronteiras, capazes de fabricar concórdias. [...] Agora pergunto: explodiram na inteira realidade? Diz-se, em falta de verbo. Porque de um explodido sempre resta alguma sobra de substan-cia. No caso, nem resto, nem fatia. Em feito e desfeito, nunca restou nada de seu original formato. Os soldados da paz morreram? Foram mortos? Deixo-vos na procura da resposta, ao longo destas páginas. (COUTO 2004, 12; sublinhado meu)

Como compreendê-las, então, na economia ficcional e no universo efabulató-rio de $O$ Último Voo do Flamingo? Não deveríamos nós procurar «a causa das ex-plosões» igualmente por dentro das tradições da cultura ocidental, se o mundo de Tizangara é, também, um espaço outrora colonizado? A razão pela qual se investe aqui, no lugar da voz narradora, a 
figura do «tradutor» tem, por certo, que ver com a importância dessa figura, no pensamento poético do autor:

O meu país tem países diversos dentro, profundamente divididos entre universos culturais e sociais variados. Eu mesmo sou prova desse cruzar de mundos e de tempos. [...] Nasci num tempo charneira, entre um mundo que nascia e outro que morria. Entre uma pátria que nunca houve e outra que ainda está nascendo. Essa condição de um ser de fronteira marcou-me para sempre. As duas partes de mim exigiam um médium, um tradutor. (COUTO 2009, 123; sublinhado meu)

Mas a importância do seu estatuto de «tradutor de mundos»-como é consa-bidamente o caso, em O Último Voo do Flamingo - por certo se compreenderá melhor se tivermos em consideração, em alguns dos seus textos de intervenção crítica, não apenas a) a forma como concebe aquilo a que chama de «mundo», mas também b) a diversidade etnolinguística e geocultural de um país como Moçambi-que, cujas fronteiras políticas e territoriais foram herdadas do poder colonial. No primeiro caso, contrariamente à ideia ocidental e europeia de «meio ambiente» - «que pressupõe que nós humanos estamos no centro e as coisas moram à nossa volta» (Ibidem: 23)... - é, do ponto de vista de Mia Couto, necessário estarse aberto à noção de «mundo» tal como ela resulta da experiência rural africana:

$\mathrm{Na}$ realidade, as coisas não nos rodeiam, nós formamos com elas um mesmo mundo, somos coisas e gente habitando um indivisível corpo. Esta diversidade de pensamento sugere que talvez seja necessário assaltar um último reduto do racis-mo que é a arrogância de um único saber e a incapacidade de estar disponível para filosofias que nos chegam das nações empobrecidas. (Ibidem)

Ora, a esse «mundo» assim concebido - que deixaria então de ser exclusiva-mente «nosso» na medida em que, por outro lado, lhe passaríamos a pertencer, ou em que ele nos retiraria da centralidade de que nos pensamos investidos, ao menos nas culturas urbanas... - pertence, também, a «língua» que falamos e que nos di i. A «tendência de mudança» - na aprendizagem linguística e na alfabetização de um país que assume uma «língua tomada de empréstimo do colonizador para negar o passado colonial» - «coloca em confronto mundos que não são apenas linguistica-mente distintos» (Ibidem: 17). Pois nele: «os idiomas existem enquanto parte de universos culturais mais vastos» (Ibidem).

Nem sempre as palavras servem de ponte na tradução desses mundos diversos. Por exemplo, conceitos que nos parecem universais como Natureza, Cultura e Sociedade são de difícil correspondência. Muitas vezes não existem palavras nas línguas locais para exprimir esses conceitos. Outras vezes é o inverso: não existem nas línguas europeias expressões que traduzam valores e categorias das culturas moçambicanas. (Ibidem, 18)

Em O Último Voo do Flamingo dir-se-ia que a situação é justamente essa: fal-tariam, ao português, termos para exprimir a forma como haveriam tido lugar tais mortes. Ou ainda, como diria Homi Bhabha, em «How Newness Enters the World: postmodern space, postcolonial time and the trials of cultural translation»:

[...] the subject of cultural difference becomes a problem that Walter Benjamin has described as the irresolution, or liminality, of 'translation', the element of resistance in the process of tranformation, 'that element that does not lend itself to translation'. (BHABHA 1994, 224; sublinhado meu)

https://periodicos.unifap.br/index.php/letras

Macapá, v. 8, n. 3, $2^{\circ}$ sem., 2018 
Esse espaço liminar é, portanto, aquele em que é possível ver marcar-se, não só a «diferença cultural» enquanto limite da língua - e dos sistemas de representa-ções culturais e da práxis que ela supõe, no terceiro espaço... - mas a descontinui-dade temporal que aí se inscreverá, no movimento de uma transição irredutível a qualquer espécie de continuum histórico. Esse espaço intersticial é o lugar da emer-gência performativa da «novidade» [newness], na mimicry que a «tradução cultural» - como repetição deslocadora - pressupõe. Por isso nos diz o narrador-«tradutor» de $O$ Último Voo do Flamingo que: «O que se passou só pode ser contado por palavras que ainda não nasceram» (COUTO 1987, 11). É, em suma, aquele espaço interva-lar em que se faz a experiência do que, em «A Tarefa do Tradutor», de Walter Ben-jamin, se dá como da ordem da estranheza - da «estrangeiridade» [foreigness]... - na inconciliação entre os modos de dižer próprios de cada língua, quando duas lín-guas se confrontam na sua estranheza (BENJAMIN 2015, 97-98).

This space of the translation of cultural difference at the interstices is infused with that Benjaminian temporality of the present which makes graphic a moment of transition, not merely the continuum of history; it is a strange stillness that defines the present in which the writting of the historical transformation becomes uncannily visible. [...] Cultural translation dessacralizes the transparent assumptions of cultural supremacy, and in that very act, demands a contextual specificity, a historical diffe-renciation within the minority positions. (BHABHA 1994, 224; sublinhados meus)

Ora, não seria a privação de um termo adequado para descrever aquelas mortes já, de si mesma, indicativa dessa falta de transparência em relação ao real indutora de uma tal «dessacralização» do português? Vejamos então, mais de perto, o que se passa em O Último Voo do Flamingo...

\section{«Explodiram, na inteira realidade?»}

Uma comparação dos depoimentos reunidos por Massimo Risi e, mais tarde, transcritos - por uma espécie de mallarmeana inspiração - para "português visiveli» (COUTO 2004, 11; cf. BLANCHOT 1949, 39) pelo tradutor de Tizangara permitir-nos-á, contudo, observar aspectos que não vimos tratados por nenhum dos ensaios atrás mencionados. O que dos «soldados da paz» restava das explosões era, por um lado, o seu sexo decepado. Assim - «nu e cru, eis o facto: apareceu um pénis decepado, em plena Estrada Nacional, à entrada de Tizangara. Era um sexo avulso e avultado» (Ibidem, 17; sublinhado meu), um «sexo maiusculino» (Ibidem, 34), como diria Ana Deusqueira, a prostituta de Tizangara. E é então que alguém sugere:

- Olhem lá no cimo da árvore! Era um desses bonés dos soldados das Nações Unidas. Pendurado num galho balançava na vontade das brisas. No instante que se confirmou a identidade da boina foi como navalha golpeando a murmuração. E logo-logo a multidão se irresponsabilizou. [...] E destroçaram, todos destrocados. Sobre o asfalto quente ficou o apêndice órfão. No ramo seco restou o chapéu missionário, plenamente só no meio das aragens. Azul em fundo de azul. (Ibidem, 18).

A pergunta é, pois, a seguinte: por que razão essa desaparição se haveria de marcar assim, no romance? O que poderia, portanto, ela significar - «azul em fundo az̨ul - para além de se constituir já como um obstáculo adicional à elaboração de qualquer relatório plausível? Com efeito, é precisamente por aí que o problema de «tradução» começa... No diálogo do ministro com o chefe da delegação da ONU: 
- Não me venha com essa merda dos explodidos. Desculpe lá mas essa não engulo. [...] / Escute bem: já desapareceram cinco soldados. Cinco! Eu tenho que dar relatório aos meus chafes em Nova Iorque, não quero estórias nem lendas. / [...] E ouça: quero tudo gravado. Não quero blá-blá, estou cansado de folclore. (Ibidem, 32-33)

Mas uma observação mais atenta constataria, por outro lado, o seguinte: que se tratava aí, de uma morte sem efusão de sangue... Vejamos alguns dos testemunhos. Por exemplo, o de Estêvão Jonas, na sua correspondência:

Já eu me deitava sobre ela, quando o clarão recintilou, parecia o cosmos se rasgava em dois. Me berlindaram os olhos. [...] Foi quando vi voar em minha direcção um órgão de macho, mais veloz que a fulminância de um relâmpago. [...] Depois de um tempo, aquele mesmo povo se acumulou junto ao galinheiro. Lá em cima estavam as botas do desditoso. E mais nenhum sinal: nem sangue nem vísceras, nem cheiro sequer. (Ibidem: 94-95; sublinhado meu)

Ou ainda o de Ana Deusqueira, que se deitara com um dos soldados mortos:

Fechei os olhos. Eu já tinha ouvido falar disso, dos estrangeiros explodirem quando montam nas meninas. Porém, nunca tinha acontecido comigo, nunca. Eu não queria nem abrir os olhos, ver a sangraria toda espalhada, tripas dependuradas nos candeeiros. Mas, afinal, não tive de limpar nada. O homem explodira que nem um balão. Aquele vivente se tinha espatifurado sem vestígio. (Ibidem, 185; sublinhado meu)

Ou ainda a versão do feiticeiro Zeca Andorinho:

Analise bem: o que é que resta dos explodidos? Uma perna? Um olho? Uma orelha? Só sobram as pichotas dos gajos. Sim, o resto se evapora. Já me foi visto homem sem pila. Mas agora, pila sem homem, me desculpe. O senhor me olha, zi-guezagueando. [...] Então lhe inquiro mais: por onde foi o sangue dos arrebenta-dos? Por onde que nunca sobrou nem gota? (Ibidem, 158; sublinhado meu)

E, no entanto, em Tizangara, outras mortes tinham lugar. E essas implicavam derramamento de sangue. Como notaria a mesma Ana Deusqueira:

É que no meio de tudo há sangue, mortos a quem não cobriram o rosto. Esses mor-tos dormiram ao relento, impurificaram a noite. Para o senhor [Risi], com certeza, isso não traz gravidade. Aqui não é a morte, mas os mortos que importam. Ainda vai morrer mais gente, lhe asseguro. Não faça essa cara. Espero que a desgraça lhe passe nas suas costas, a si que me parece um homem bom. (Ibidem, 181-182; sublinhado meu)

Tratar-se-ia, pois, de mortos a quem não tinham coberto o rosto: mortos cuja expressão nos interpelaria ainda - assombrando-nos. O mesmo constaria do teste-munho de Sulplício que, ao som de uma das explosões, se pronunciaria assim:

- Esta é uma explosão das outras. / - Das outras? Que outras? / E me revelou, lacónico: era mentira que só explodissem soldados estrangeiros. Havia, segundo ele, outras explosões que matavam a nossa gente. Explosões verdadeiras, com prova de sangue e de lágrima. Como esta que tinha acabado de acontecer. / - Pai, me diga o que o senhor sabe... Com um gesto agitou negativamente o braço: nada, já tinha falado de mais. (Ibidem, 144)

Quem o confirmaria seria, de resto, Temporina. Essa morte com derramamento de sangue acabaria por atingir seu irmão: 
- Mataram meu irmão. Seu único irmão, o moço tonto que herdara os bens de Hor-tênsia. A notícia era triste e colocava um novo elemento em toda aquela estória. O moço explodira. Desta vez, porém, era uma explosão real, dessas a que a guerra já nos havia habituado. (Ibidem, 147)

Que vida se esvaía, então, nessa sua morte?

O moço era lento e tonto, com tanto atraso na mente quanto no gesto. Nunca uma ideia visitara a sua cabeça e ele vivia tranquilo com a satisfação de um santo depois do pecado. O moço não era um fulano, nem um indivíduo. Assim, nem nome nenhum lhe foi posto. Valia a pena desperdiçar um nome humano num ser de quem se duvidavam as propriedades? (Ibidem, 66)

E como fora aquilo acontecer?

Tão simples quanto cruel: o moço pisara uma mina e as suas pernas se separaram do corpo como um esfarrapado boneco de trapos. Antes de chegar qualquer socorro se esvaíra em sangue. (Ibidem, 147)

O que poderia significar, então, essa diferença? Em «Sobre a Crítica do Poder como Violência», Walter Benjamin observa-nos, referindo-se às formas de comporta-mento com que, na sua experiência quotidiana, os homens lidam: «a cólera por exemplo, leva-os a evidentes explosões de violência, uma vez que não se rela-ciona, enquanto meio, com um fim proposto» (BENJAMIN 2010, 65). E acrescenta Benjamin: «tais manifestações encontramse, em primeiro lugar e de forma muito significativa, no mito» (Ibidem). O exemplo que o atesta é a história mitológica de Níobe. Por ter depreciado Leto, ela acaba por ver os seus filhos mortos por Apolo e Artemisa (GRAVES 1990, 227-228). Assim:

O poder mítico, na sua forma arquetípica, é mera manifestação dos deuses. Não meio para os seus fins, dificilmente manifestação da sua vontade, em primeiro lugar manifestação da sua existência. A lenda de Níobe contém um exemplo excelente desse poder. Poder-se-ia pensar que a acção de Apolo e Artemisa é apenas um castigo. Mas o seu poder representa muito mais a institucionalização de um Direito novo do que a punição pela transgressão de um existente. (BENJAMIN 2010, 65)

Porque não é, então, uma punição? Porque não se exerce na vigência de um direito préexistente. De facto, se ela «institucionaliza um Direito novo» é porque a violência do poder «mítico» sobre Níobe «não é propriamente destruidora» (Ibidem). Se o fosse tê-la-ia morto também. Se ganha força reguladora, é por passar a ser para efeitos da instituição de um Direito a respeitar que Níobe é poupada:

Apesar de provocar a morte sangrenta dos [sete] filhos de Níobe, suspende-se perante a vida da mãe, que deixa para trás mais culpada que antes, carregando eterna e mudamente essa culpa, um marco que assinala a fronteira entre os homens e os deuses (Ibidem; sublinhado meu)

A violência instituidora de direito é, portanto, não apenas fundadora de um direito, mas também, uma vez entendida a partir das suas origens míticas, san-grenta. Por isso não se deveria confundi-la com aquela outra a que Benjamin chama divina: "podemos confrontar com a lenda de Níobe [...] o juízo divino sobre o bando de Corah» (Ibidem, 67). Com efeito, na história bíblica da revolta de Corah e do «bando» que o acompanha, apresenta-se ele com «Datan e Abiram [...] com On». Comparecem eles com «duzentos e cinquenta filhos de Israel, príncipes da congre-gação e pessoas de posição» (COSTA 1978, 195) diante de 
Moisés e de Aarão, para contestar a sua liderança: «já basta da vossa parte! Toda a congregação é santa, todos são santos e no meio está o Senhor: porque então vos erigis em chefes de assembleia do Senhor?» (Ibidem). Ora, para dar a reconhecer os eleitos de Deus, Moisés servir-se-á, então, da diferença entre a morte natural e a morte divina - não sangrenta - como critério:

«Se esta gente morrer como todos os homens morrem; se o destino comum dos homens for também o deles, não foi o Senhor que me enviou; mas se o Senhor operar um fenómeno; se a terra abrir o seu seio para os engolir com tudo o que lhes pertencer, e se eles descerem vivos ao sepulcro, então sabereis que estes homens ofenderam o Senhon». (Ibidem, 196)

E a punição divina, invocada por Moisés, logo se confirmaria:

Ora, logo que acabou de pronunciar estas palavras o solo que os sustentava fendeu-se. Abriuse o seu seio e devorou-os, a eles e às suas casas, a todos os homens de Coré [isto é, de Corah ou de Korah] e a todos os seus bens. Desceram vivos ao sepulcro, eles e todos os seus: a terra fechouse sobre eles e desapare-ceram do meio da congregação. (Ibidem; sublinhado meu)

Que pensar desse «juízo» divino, que se abate sobre «o bando de Corah»?

Esse juízo abate-se sobre os privilegiados, levitas. Atinge-os sem aviso prévio, sem ameaça, castigando e não hesitando em aniquilá-los. Mas ao mesmo tempo, ao aniquilar absolve da culpa, e não se pode negar uma profunda relação entre o carácter não sangrento e a absolvição patentes nesse poder. O sangue, de facto, é simbolo da vida nua. (BENJAMIN 2010, 68; sublinhado meu)

Aproximamo-nos aqui de um indicador-chave... Se o sangue é o símbolo da vida nua, «O que é que distingue essencialmente a vida humana da dos animais e das plantas?» (Ibidem: 69). Para W. Benjamin, a vida nua, em si mesma considerada - da qual os seres humanos «vivos» participam... - não os esgota no seu ser, enquan-to tal. Assim, se a repressão sangrenta, instituidora de Direito, se abate sobre os vivos - de que os filhos de Níobe são aqui um exemplo... - é porque ela não chega a distingui-los da vida nua de que eles participam sem, por isso, a ela exclusiva-mente pertencerem ou a ela se reduzirem. Quanto à violência divina - não san-grenta - que cai sobre «o bando de Corah», observará Walter Benjamin:

Nesta medida será também legítimo designar este poder como aniquilador; mas é-o apenas de uma forma relativa, em relação a bens, ao Direito ou à vida, mas nunca absoluta, em relação à alma do ser vivo. [... Pois] É falso e vil o postulado de que a existência em si está acima de uma existência justa, se por existência não se entender mais do que a vida nua [...]. (Ibidem, 69, sublinhado meu)

Seria já, acrescenta Benjamin, o que se escutaria no mandamento bíblico: «Não matarás». A «O argumento de que, segundo a sua lógica, ela permitiria também, em determinadas condições, a violência letal dos homens uns contra os outros» (Ibidem, 68), ele responde que «o argumento não colhe, pois à pergunta 'Posso matar?' segue-se, como mandamento, a resposta irrefutável: 'Não matarás!’» (Ibidem). Signi-ficaria isto que o mandamento condena toda e qualquer morte violenta? Não, pois, como Benjamin acrescenta: «Do mandamento não pode deduzir-se qualquer julga-mento do acto. Por esta razão não se pode prever, nem o juízo divino do acto, nem a razão desse juízo» (Ibidem; sublinhado meu). Daí a seguinte consequência: 
E por isso não têm razão aqueles que pretendem fundamentar com o mandamento a condenação de toda e qualquer morte violenta de um ser humano por outro. Ele [o mandamento] não constitui medida de julgamento, é antes guia para a acção das pessoas ou comunidades que a ele recorrem na sua solidão e em casos inauditos assumem a responsabilidade da transgressão. (Ibidem: 68-69)

Observará Jacques Derrida, em Força de Lei, a este propósito:

$\mathrm{O}$ «não matarás» permanece um imperativo absoluto, a partir do momento em que o princípio da violência divina mais destrutiva ordena o respeito pelo vivente, para além do direito, para além do juįo. Porque este imperativo não é seguido por nenbum juiฑo. Não fornece nenbum critério para julgar. Não se podia apelar a ele a fim de condenar automaticamente toda a condenação à morte. (DERRIDA 2003, 93; sublinhado meu)

Assim, se «a violência divina mais destrutiva ordena o respeito pelo vivente» (Ibidem) é necessário que este eleja, não «a vida por si mesma» - pois Walter Benjamin, lembra-o Derrida, «ergue-se com todo o vigor contra a sacralização da vida por si mesma» (Ibidem) - mas «a vida enquanto ela se prefere» (Ibidem: 94; sublinhado meu). O que nesse princípio se consagra é, portanto:

[...] a vida para além da vida, a vida contra a vida, mas sempre na vida e para a vida. [...] O que faz o preço do homem, do Dasein e da sua vida, é conter a possibi-lidade da justiça, o porvir da justiça [... pois] o que é sagrado na sua vida não é a sua vida, mas a justiça da sua vida» (Ibidem, 94; sublinhado meu).

A vida para além da vida nua e contra ela: a «vida justa» ou que contenha a possibilidade da justiça. Enquanto violência justa, a «violência divina» seria, portan-to, não apenas sem efusão de sangue, mas também em favor de uma «vida que se prefere» - vida que a si mesma se respeita e que, por esse respeito, se justificaria aos olhos de Deus. Tratar-se-ia, assim - na violência sangrenta e nãosangrenta - de duas violências de sinal contrário:

Dito de outro modo, a violência mitológica [grega, fundadora] do direito satisfaz-se em si mesma sacrificando o vivente, enquanto a violência divina sacrifica a vida para salvar o vivente, a favor do vivente. Em ambos os casos há sacrifício, mas no caso em que o sangue é exigido, o vivente não é respeitado. (Ibidem, 92-93; sublinhado meu)

E é precisamente «aí [que] reside, para Benjamin, a essência do judaísmo, que recusaria expressamente condenar o assassinio em caso de legítima defesà) (Ibidem; sublinhado meu). Como é que estas posições nos podem ajudar na com-preensão daquilo de que se trata, em $O$ Último $\checkmark$ oo do Flamingo?

\section{A igreja do padre Muhando junto ao rio: as pegadas de Deus...}

Para se entenderem as implicações desta aproximação, seria preciso começar por escutar, com alguma atenção, a versão do padre Muhando... Não nos limitar-mos a assinalar a descoberta da autoria do crime da reimplantação das minas - como acontece com vários dos seus comentadores (cf. ROTHWELL 2015, 182; BRUGIONI 2012, 88): a de Ana Deusqueira. Mas escutar aquilo de que o padre «já suspeitava» - é o seu testemunho - e que só o descrédito em que caíra, por causa da bebida, lhe não permitira denunciar. O padre Muhando, a cujo círculo de amigos pertenciam - ver-se-á a importância disto - Zeca 
Andorinho e Suplício, e cuja compreensão do que está em jogo, em Tizangara, parece transcender, em muito, a descoberta de Ana Deusqueira. Que nos diz então Muhando?

Passava-se, afinal, o seguinte: parte das minas que se retiravam regressava, depois, ao mesmo chão. Em Tizangara tudo se misturava: a guerra dos negócios e os negócios da guerra. No final da guerra restavam minas, sim. Umas tantas. Toda-via, não era coisa que fizesse prolongar tanto os projectos de desminagem. O di-nheiro desviado desses projectos era uma fonte de receita que os senhores locais não podiam dispensar. (COUTO 2004, 200)

Nesse «negócio da guerra», por conseguinte, «umas mortes à mistura até ca-lhavam, para dar mais crédito ao plano» (Ibidem). Mas isso surtiria efeito enquanto se tratasse das mortes de «gente anónima, no interior de uma nação africana que mal sustenta seu nome no mundo. Quem se ocuparia disso?» (Ibidem) O problema é que esse projecto não contara com a vinda dos capacetes azuis:

- Mas depois veio esse desacontecimento! / - Qual desacontecimento, padre? A morte dos capacetes azuis. Terem explodido estrangeiros foi o que desmontou o esquema. $\mathrm{O}$ feitiço dos estrondeados prejudicou a trapaça. Se atraíram atenções indevidas. A verdade das minas pedia provas de sangue. Mas sangue nacional. Nada de hemorragias transfronteiriças. (Ibidem)

O administrador da vila de Tizangara - Estêvão Jonas - chamaria, então, o fei-ticeiro Zeca Andorinho: «deu ordem para que aquilo terminasse, de imediato. Mais nenhum soldado da ONU poderia desaparecer» (ibidem):

- E Zeca Andorinho o que respondeu? / - Zeca mentiu, disse que aquilo era feitiço de fora. Que eram fenómenos extralocais, comandados por forças maiores. E disse ele não tinha mão naquelas sobre naturezas (Ibidem, 200-201).

Porque diria, no entanto, o padre Muhando, que Andorinho mentiu? Que teria significado dizer que esse feitiço era de dentro? Em que medida, em Tizangara, fora e dentro se distinguiam? Uma resposta começará a esboçar-se à chegada de Tem-porina. Conta ela que o adjunto Chupanga conduzia já, por essa altura, o administra-dor a caminho da fronteira ao encontro de Jonassane, o primo cúmplice dos desvios de fundos. Regressado, o adjunto cumpriria, então, a missão que lhe fora atribuída: fazer rebentar a barragem do rio Madzima e, inundando tudo, destruir as provas do crime. Sulplício diz então ao filho:

- Vá meu filho, se apresse a evitar essa tragédia. Vá à barragem, antes que esse satanhoco lá chegue. [...] Leve esta pistola, mate-me esse Chupanga. / Eu não tinha ouvidos para tais palavras. Matar? Sim, matar essa minhoca que não era gente. Neguei-me, sem sangue, sem voz. / Você não tenha coração que aquilo não é homem. Simples bicho. (Ibidem: 201-202)

Diante da inicialmente silenciosa recusa de seu filho - que a isso se nega, «sem sangue, sem voz», note-se... - Sulplício insiste. Mesmo quando o filho lembra ser, seu pai, também ele pouco afeito às incumbências de qualquer execução sumária:

- Mas o senhor, pai, não se lembra? O senhor nem o flamingo matou quando lhe foi mandado. / - Já disse, dispare nos miolos desse demónio. Até aqui o padre Muhando o abençoa. Não é padre? (Ibidem, 202)

https://periodicos.unifap.br/index.php/letras

Macapá, v. 8, n. 3, $2^{\circ}$ sem., 2018 
Porque havia o padre Muhando de o abençoar? Uma correspondência com o pensamento judaico-cristão de Walter Benjamin parece-nos começar a esboçar-se. E ela estender-se-á mesmo às palavras que, de Zeca Andorinho, então, se seguem:

Zeca Andorinho tomou posse: me sacou a pistola da mão e a enfiou no cinto. E disse: - Eu mesmo farei justiça - apontando o revólver, acrescentou: - Este será o meu melhor feitiço! (Ibidem, 202-203)

Em que sentido justiça e feitiço se aliariam aqui? Pois que é, então, de uma «vida justa» - uma «vida que a si mesma se prefere» - que se trata... Haveria, no entanto, alguma relação de partilha de tais pressupostos, entre o padre e o feiticei-ro? Aquando da sua prisão, o padre Muhando «Vinha descalço, sem camisa. Seme-lhava um Cristo negro, carregando uma invisível cruz» (Ibidem, 125)... E o seu teste-munho começa por ser um tanto surpreendente:

- Que se passa? / - Prenderam um homem. / Fomo-nos aproximando dos polícias que escoltavam um homem pequeno, coxo. Estava de costas, mas, quando se virou, vi que era o padre $\mathrm{Mu}$ hando. [...] - Padre Mubando! / - Dizem que fui en que fiz as explosões. / - Que disparate! E o padre não lhe explicou? / - Expliquei, confessei tudo. / - Confessou? / - Sim. Fui eu mesmo que fiz explodir essa estrangeirada. (Ibidem)

Risi e o tradutor visitam-no, no dia seguinte, na tentativa de melhor compreen-derem o que se tinha passado:

A seguir o sacerdote pareceu disposto a prestar informação. Mas ele só fingia. Por-que explicou: o soldado explodido era um homem feio. Tinha os tomates maiores que os do boi-cavalo. Até a andar se ouviam os badalões dele. Dizia isto, não por-que os tivesse visto em vida. Os ditos voaram, póstumos, para cima do canhoeiro. E aterraram na estrada nacional, às vistas de todos. (Ibidem, 125-127)

«Fingiria» de facto? Diante desse achado, com quem se encontraria ele? Pre-cisamente com Zeca Andorinho: «o nyanga [o feiticeiro], que ele chamava de 'colega'» (Ibidem, 127). E para quê? «Para dar destino às partes do [soldado] zam-biano» (Ibidem). Porque:

Já voavam abutres de rapina sobre a copa da grande árvore. Seria chamar desgraça se se deixassem aquilos assim, à disposição dos bichos. Nunca mais haveria sossego, caso os pássaros engolissem os mbolos do estrangeiro. A biche-za não visita lugar da gente. Pelo menos, sem o devido assentimento. E o padre: - Como o senhor, que nos visita sem nos perguntar - disse, apontando o italiano. (Ibidem, 127)

O italiano fazia, portanto, parte daquela mesma bicheza, da impureza dessa vida pura e simples: de uma «vida nua», em suma... Era, pois, junto dela que ele devia estar. «O que fizeram então ele e o feiticeiro?» (Ibidem). Juntos:

Retiraram dos ramos os órgãos do infeliz e os deitaram longe no mato, lá bem nas profundezas onde só circulam os bichos indomesticados. [E para Risi] / - Devíamos lançar o senhor também lá. / O italiano já não encontrava mais graça ao escutar o relato. O padre era uma criatura digna de descrédito. Confirmava o que tinha ouvido dizer: o religioso enlouquecera, esquecendo as suas obrigações. (Ibidem) 
Porque se dizia, no entanto, que ele «enlouquecera, esquecendo-se das suas obrigações»? As razões hão-de reconduzir-nos ao problema inicial do tradutor: «Explodiram na inteira realidade?»... Pois como situar, então, uma morte que se diria, por um lado, natural - pois eles morreram em consequência da sua cupidez, do ciúme despertado nos homens pela sua presença, junto das mulheres da aldeia... Zeca Andorinho dirá mesmo, no seu depoimento:

Quer saber como ficaram capados? Ora, Excelentíssimo: cada um deixa cair o que não pode segurar. Eu, Zeca Andorinho, seguro bem as minhas dependências. Não ando por aí a meter a moca no trombone. O senhor sabe: tudo cai, até nuvem tomba do céu. Quem sofre as culpas disso? Ninguém. Estou a sério, doutor. Não sei o que aconteceu - com todo o respeito da ignorância. [...] Os anjos é que são testemunhas miloculares. O melhor é entrevistar-lhes. (Ibidem, 155)

E, por outro lado, resultante de uma punição divina - foram mortos, sem que alguém premeditadamente os matasse, por terem pisado as minas que tinham pro-vocado já outras mortes, menos transfronteiriças e internacionais: uma morte sem vísceras nem sangue. Porque se dizia, então, que o padre «enlouquecera»?

Várias vezes se ouvira o sacerdote insultando Deus pelas ruas públicas. Morria uma criança, indefesa contra o sofrimento, e Muhando saía da igreja e desafiava o Criador, ofendendo-o em frente de todos. Chamava-lhe os piores nomes. / - É verdade que ofende Deus? / - Qual Deus? I - Bom... Deus. / Ah, esse. É verda-de, sim. Eu insulto-O quando ele se descomporta. (Ibidem, 128)

A sua equacionação pagã - entre «esse Deus» e os restantes, talvez mais antigos, como veremos... - lembra-nos aqui o Ricardo Reis de «Não a ti, Cristo, odeio ou menosprezo»:

Não a ti, Cristo, odeio ou menosprezo / Que aos outros deuses que te precederam / Na memória dos homens. / Nem mais nem menos és, mas outro deus. // No Pante-ão faltavas. Pois que vieste / No panteão o teu lugar ocupa, / Mas cuida não procu-res / Usurpar o que aos outros é devido. (REIS 1987, 74)

Ora, a esse Deus - nem mais nem menos do que os outros que o precederam - por que $\mathrm{O}$ insultava o padre Muhando? É que, conforme explicava:

Tinha razões para essa intimidade - ele e Deus eram colegas, sabedores de se-gredos mútuos. Quando ele bebia, Ele bebia também. Por isso ele não rezava a Deus. Antes rezava com Deus (COUTO 2004, 128; sublinhado meu).

Essa proximidade o daria já como corresponsável por aquelas mortes: «Sim. Fui eu mesmo que fiz explodir essa estrangeirada» (Ibidem: 125). O mesmo seria dizer que tinha sido Ele - o mesmo Deus com quem ele rezava... - quem punira aquela «estrangeirada». E o seu discurso articula-se, então, com um irrepreensível rigor:

Falou tudo de enfiada rosariando as palavras como quem estivesse no esgotar do tempo. - O senhor me olha, pensa que eu sou um doido lunático. Mas tanto faz-me. / - Por amor de Deus, eu não penso nada - ripostou Massimo. - Agora, uma coisa: o senhor nunca, mas nunca me fotografe! Nem me grave. Quem é o senhor para andar a gravar e fotografar sem autorização? (COUTO 2004, 126)

Em que sentido? Diz-nos Emmanuel Lévinas, em «Interdit de la représentation où les 
droits de l'homme», um dos textos de Altérité et transcendance:

«Interdit de la représentation» - relatif d'ailleurs, dans la tradition juive, à certaines images seulement [...] on ne devrait pas laisser à la légère circuler cette formule [...] sans examiner, au préalable, de très près, ce que disent la Loi écrite de la Bible et, dans son langage à plusieures dimensions et niveaux, la Loi orale du Talmud où, d'ailleurs, quand il s'agit d'une recherche scientifique, toute représentation est authorisée. (LÉVINAS 1995, 127-128)

E porquê? Porque, tal como no caso do padre Muhando - que reza com Deus e com ele vive... - o que nessa interdição da idolatria se marca é, precisamente, uma proibição da redução da transcendência que seria o equivalente à aniquilação perpe-trada pela «paixão do assassínio». Assim, o que pela sua representação - fotografia ou gravação, diante de Risi... - se atingiria seria, então, a própria:

Unicité de l'unique dans son genre - ou unicité ayant rompu tout genre - au sens où l'aimé est unique pour l'aimant. Unicité qui, à l'aimant, d'emblée, signifie la crainte pour la mort de l'aimé. Or, dans l'image, la pensée accède au visage d'autrui réduit à ses formes plastiques, fussent-elles exaltées et fascinantes et procédant d'une imagination exacerbée. Fussent-elles oeuvre d'art! (Ibidem, 128-129)

Único, na sua proximidade e, nisso, tão (co-) responsável como irrepresentável...

Dans l'interdit de la représentation» on ne met pas seulement en question le privilè-ge exclusif que la culture occidentale aurait conféré à la conscience et à la science qu'elle porte en elle et qui, conscience de soi, se promettrait ultime sagesse et pen-sée absolue. (Ibidem, 131)

Do que se tratara fora sempre daquela abusiva redução do outro que foi mere-cendo - na frente anti-colonial do combate pela liberdade, ou no esforço pela auto-determinação, enquanto exercício do direito de separação (e sabe-se o quanto esta palavra vale, no léxico de Lévinas)... - a mesma contestação que lhe deveria mere-cer todo o ódio ou o desejo de matar.

Question qui ne se soulève certainement pas parce que la représentation ne serait vouée qu'à la matérialité de la chose, comme si elle était incapable de d'abstrac-tions et ne pouvait pas viser le non-matériel. Mais parce que, dans la présence qu'elle ne cesse pas de renouveler, s'accomplit toujours l'adéquation de la pensée à son autre; parce que, intentionnalité, elle vise toujours «quelque chose»: un but, une fin, un fini, un terme. (Ibidem; sublinhado meu)

Ora, não é Deus infinito? Procurar reduzi-l'O às suas (inencontráveis) feições plásticas... Não seria isso já conforme a uma certa «paixão do assassínio»?

\section{Sulplício e «o bando de Corah»: um céu debaixo da terra...}

Mas não eram só o padre Muhando e Zeca Andorinho que entravam no círculo dessa proximidade. Também Sulplício, que replicaria, ao adjunto Chupanga, quando este lhe manifesta a intenção de lhe vir a oferecer, um dia, um cargo político:

- Até já tinha pensado em lhe oferecer a responsabilidade aqui da secção de Ti-zangara. Você tem a aceitação das massas. [...] / - Você não entende, eu só aceitaria se ficasse a dirigir mais alto. / - A nível de província? / - Mais alto. / - Da nação? / - Mais alto, muito mais alto. (COUTO 2004, 208) 
Em que sentido iria, então, essa sua ambicionada altura?

Os outros acreditavam ser mania de grandeza. Contudo men pai, só eu sabia, refe-ria-se a outras dimensões, a outra altura. Essa inatingivel, onde nem homens nem suas infelicidades se distinguem. (Ibidem; sublinhado meu)

Não espantaria, pois, ouvir Sulplício responder - depois de lhe haver prometido «mostrar o que aconteceu com os soldados explodidos》 (Ibidem, 210):

- Então, senhor Sulplício: vai ou não vai me explicar a razão dos desapareci-mentos dos meus homens? / - Não sou eu que irei falar. Quem vai falar é este lugar. / - O lugar? / - Sim, este mesmo lugar. É por isso que viemos aqui, senão eu já tinha falado lá na vila. (Ibidem, 218)

Que tinha pois esse lugar? "Meu pai explicou: ele só podia falar no lugar que lhe era sagrado, junto ao rio Madzima. [...] - Sigo o padre Mubando: neste lugar também eu converso com Deus» (Ibidem; sublinhado meu). Onde ficava esse lugar? Justa-mente ali, onde o padre Muhando tinha a sua «igreja»:

- Sabe onde é a minha verdadeira igreja? Sabe? É junto ao rio, lá no meio dos ca-niços. Subiu a um caixote e espreitou da janela [da prisão]. [...] - Veja. É ali que converso com Deus. / Porquê ali? / - Porque é ali que estão as pegadas de Deus. [...] - Ali naqueles caniços: aquela é a minha igreja. Lá eu me debruço para olhar os olhos de Deus. Falo com ele através da água. (Ibidem, 128-129)

Que «explicação» advirá, então, desse lugar? Eis o que o tradutor nos diz:

Foi num súbito: acordei em sobressalto. É que no meu rosto senti o bafo das infer-nezas. Olhei para o lado e quase desfaleci: ali mesmo, onde estava a terra, não havia nada senão um imenso abismo. Já não havia paisagem, nem sequer chão. Estávamos nas margens de um infinito buraco. (Ibidem, 219; sublinhado meu)

Que acontecera então?

Como a inteira paisagem, a casa, a vila, a estrada. Tudo engolido pelo vácuo. Um homem faz um grande buraco, sim. Muitos homens fazem um buraco muito enorme. Uma cova daquela dimensão, porém, aquilo era obra da sobrenatureza. Chamámos o italiano que se inacreditou: o país inteiro desaparecera? Sim, a nação fora toda engolida nesse vácuo. (Ibidem, 219; sublinhado meu)

Razão haveria tido o «tradutor» para, logo no início do romance, nos confi-denciar: «em Tizangara, só os factos eram sobrenaturais. E contra factos tudo eram argumentos» (Ibidem, 17). Como com «o bando de Corah», tudo e todos teriam então resvalado chão abaixo. Sumido por esse céu que haveria debaixo da terra - sepulcro abaixo... - por essa imensa pegada de Deus. Na versão de Sulplício:

Já acontecera com outras terras de África. Entregara-se o destino dessas nações a ambiciosos que governavam como hienas, pensando apenas em engordar rápido. [...]. Vendo que solução não havia, os deuses decidiram transportar aqueles países para esses céus que ficam no fundo da terra. [...] Nesse lugar onde nunca nada fizera sombra, cada país ficaria em suspenso, à espera de um tempo favorável para regressar ao próprio chão. (Ibidem, 220-221; sublinhado meu) 
E nesse limbo permaneceriam ainda, pois:

Até lá era o vazio do nada, um soluço do tempo. Até lá gente, bichos, plantas, rios e montes permaneceriam engolidos pelas funduras. Se converteriam não em espíri-tos, pois essas são criaturas que ocorrem depois da morte. E aqueles não haviam morrido. Transmutaram-se em nãoseres, sombras à espera das respectivas pes-soas (Ibidem; sublinhados meus).

Haveria diferença aqui, entre esta versão e a bíblica - posto que não baviam morrido? Claro que não. Sulplício perguntaria então:

- Está a entender, senhor Massimo? / - Mais ou menos... [...] Isto nem lembra ao diabo. / _ Falou em diabo. E acertou. Pois the explico... / - Dispenso mais expli-cações. O diabo explicava, sim. Podia bem ser que aquele buraco tivessem sido os deuses que quiseram enterrar os demónios que engordavam na nossa terra. Mas eram tantos que tiveram que cavar fundo. Mais fundo que o próprio mundo. (Ibidem)

Talvez Risi pudesse tê-lo entendido se, nessa altura, preocupado com a implau-sibilidade do relatório sobre as mortes dos soldados, de que dependia a sua progressão de carreira na ONU, se não tivesse esquecido, momentaneamente, de Temporina, a «velha-moça» por quem se apaixonara em Tizangara. Quem era ela?

A mulher, toda ela cheirava a glândula. Podia uma velha com tamanha idade inspirar desejos num homem em plenas faculdades? Massimo Risi se apressou a sair. De passagem pela recepção, aproveitou para recolher informações sobre a idosa mulher. - Ah, essa é Temporina. Ela só anda no corredor, vive no escuro, desde bá séculos. / - Nunca sai? / - Sair?! Temporina? [...] Ela é uma dessas que anda, mas não leva a sombra com ela. (Ibidem, 41)

Ora, falando «nesse lugar onde nunca nada fizera sombra, [e] cada país ficaria em suspenso, à espera de um tempo favorável para regressar ao próprio chão», era também de Tizangara que o velho Sulplício falava. E de Temporina:

- Tenho cara de velha porque recebi um castigo dos espiritos. / - Madonna zinga-ra! - repetia o italiano. [...] Ajudei na explicação. Eu conhecia Temporina, ela era apenas um pouco mais velha que eu. Era verdade: ela não aceitara nenhum namoro enquanto moça. Quando deu conta, tinha-se passado o prazo da sua adolescência. Mais que o permitido. E assim desceu sobre ela uma punição divina. (Ibidem, 64)

Em que consistira então essa punição (e não expiação)? Risi esbarrara-se com ela na penumbra dos corredores da pensão:

Ajudou-a a erguer-se, conduziu-a até à porta do quarto ao lado. É que o pano deixava entrever um corpo surpreendentemente liso, de moça polpuda e convida-tiva. Era como se aquele rosto encarquilhado não pertencesse àquela substância dela. [...Ora] Numa só noite seu rosto se preencheu de ruga, se perfez nela todo o redesenhar do tempo. Contudo, no restante corpo, ela guardava sua juventude. (Ibidem, 41; 64)

Temporina era, portanto, uma alegoria do quanto tanto a vila como todas aquelas nações africanas se não haviam ainda cumprido. Por exemplo:

Eu sabia, como todos na vila: o administrador Jonas tinha desviado o gerador do hospital para os seus mais privados serviços. Dona Ermelinda, sua esposa, tinha vazado os equipamentos

https://periodicos.unifap.br/index.php/letras

Macapá, v. 8, n. 3, $2^{\circ}$ sem., 2018 
públicos das enfermarias: geleiras, fogão, camas. Até saíra num jornal da capital que aquilo era abuso do poder. Jonas ria-se: ele não abusava; os outros é que não detinham poderes nenhuns. E repetia o ditado: cabrito come onde está amarrado. (Ibidem, 20)

E quando chama «o tradutor» à administração - e o nomeia para essa missão Estêvão Jonas se denuncia já, no aparente despropósito da sua nomeação:

- Mandei-lhe chamar porque precisamos de uma acção mais que imediata. [...] A Voz do administrador Estêvão Jonas tremia quando apontou para mim e disse: - Pois você fica, de imediato, nomeado tradutor oficial. / - Tradutor? Mas para que língua? / - Isso não interessa nada. Qualquer governo tem seus tradutores. Você é o meu tradutor particular. Está compreender? [...] - Inglês, alemão. Uma qualquer. Desenrasca-se. (Ibidem, 20-21)

Ora, filho de Sulplício, cuja mulher admirara, em tempos, o outrora guerrilheiro Estêvão Jonas - seria ele o seu verdadeiro pai? - o tradutor vem a desobedecer-lhe:

Era um enviado da administração. Entregou-me um envelope: - É uma carta de Sua Excelênciadepois, se aproximou mais para me segredar: - Ele disse para você ler primeiro. E só traduzì depois para o estrangeiro um resumo da carta. Não procedi segundo aquelas instruções. Esperei que o mensageiro se afastasse e me sentei na sombra. Li alto para Massimo Risi o inteiro conteúdo da carta. (Ibidem, 71)

A sua desobediência começara já pela sua incompreensão. Pressente-o Estê-vão Jonas:

- Quando mandei que fosse meu tradutor você não entendeu - disse Estêvão Jonas assim que me sentei. / - Desculpe, não percebo. / - Está a ver? Continua sem entender. Você não entende o que eu quero de si. / - E é o quê, Excelência? Vigiar essa cabrão desse branco. Esse italiano que anda por aí a cheirar nos recan-tos alheios. (Ibidem, 124)

Ali mesmo, diante da sua incompreensão, o administrador abre, então, o jogo:

- Mas eu pensei que ele nos vinha ajudar. / - Ajudar?! Você não sabe? Ninguém ajuda ninguém, nesse mundo da actualidade. Não conhece o ditado: morcego faz sombra é no tecto? O administrador, depois, confessava: tinha colocado Chupanga para me espiar. O esquema dele era uma tripla espionagem: eu espiava o italiano, Chupanga me espiava a mim e ele, por último, nos espiava a todos nós. (Ibidem)

E acrescenta, então: - E digo sinceramente, tenho dúvidas por causa de seu pai. (Ibidem). Ora, tais dúvidas não seriam de todo infundadas. Quer no mais auto-irónico sentido, quer no outro. Posto que Sulplício convenceria o filho tanto da juste-za da sua posição como tradudor quanto da justiça do seu testemunho:

- Antes de ir ainda lhe digo uma coisa: é que está muito certo. / - Está certo o quê, pai? / - Você ser tradutor. E falou a explicação que jamais ouvira. Eu era um filho especial: desde cedo meu pai notara que os deuses falavam por minha boca. É que eu, enquanto menino, padecera de gravíssimas doenças. A morte ocupara, essas vezes o meu corpo, mas nunca me chegara a levar. Nos saberes locais, aquela resistência era um sinal: eu traduzia as palavras dos falecidos. (Ibidem, 143)

Como dizer, então, que os soldados morreram sem morrer naturalmente, embora tivessem sido mortos sem assassinato, por uma «punição» divina que os castrasse, deixasse em suspenso, fulminasse? Com razão protesta seu filho, na nota preambular do romance: 
$\mathrm{Na}$ altura dos acontecimentos, eu era tradutor ao serviço da administração de Ti-zangara. Assisti a tudo o que aqui se divulga, ouvi confissões, li depoimentos. Colo-quei tudo no papel por mando de minha consciência. Fui acusado de mentir, falsear as provas de assassinato. Me condenaram. Que eu tenha mentido, isso não aceito. Mas o que se passou só pode ser contado por palavras que ainda não nasceram. (COUTO 2004, 11; sublinhado meu)

Intuição que o colocaria na mesma posição que Zeca Andorinho - o «nyanga» a quem o padre Muhando trata por «colega». No seu depoimento a Risi, Zeca dirá:

Me escute, senhor: estou vivendo apenas em rascunho, amanhando uns biscatos de futuro. É que aqui, na vila, ninguém nos garante. [...] Agora o senhor me pergun-ta por esses soldados que desapareceram-se. Pergunta-me se o soldado zambiano morreu. Morreu? Bem, morreu relativamente. Como? O senhor me pergunta - como se morre relativamente. Não sei, não lhe posso explicar. Teria de falar na minha lingua. (COUTO 2004, 156-157; sublinhados meus).

Falando em português, Andorinho não falava pois - já e ainda... - na sua lingua. Antes num idioma que permanecia, em grande medida, alheio ao mundo que lhe era próximo. Se a sua condição era a daqueles a quem, na vila, nada se garante - «Até o chão nos arrancam» (Ibidem,156) - tal acontecia, igualmente, na experiência do desencontro das línguas em que se exprime. No chão dessas línguas - que assim lhe foge como se uma enorme fenda nele se abrisse... - se joga, então, o seu futuro, a sua sobrevivência: «Digo isto por vistoria: não confianço em ninguém, estamos a ser empurrados para onde não há lugar nem data certa» (Ibidem; sublinhado meu). Precisando de reformular o português a partir da sua língua materna ele está «vivendo em estado de rascunho»... Daí esse conceito de morte relativa ser...

[...] coisa que nem este moço não pode traduzir. Para o que havia que falar não há palavras em nenhuma língua. Só tenho fala para o que invento. [...] Está a ver minha educação? Falam muito de colonialismo. [...] O que fizeram esses brancos foi ocuparem-nos. Não foi só a terra: ocuparam-nos a nós, acamparam no meio das nossas cabeças. Somos madeira que apanhou chuva. Agora não acendemos nem damos sombra. Temos de secar à luz de um sol que ainda não há. (Ibidem, 158)

Assim, para que se entenda aí a modulação de sentido trazida pelo advérbio - nesse «morrer relativamente»... - é preciso fazer intervir a noção de um fim que a sua cultura não reconhece. Pois, como ele dirá, a certa altura, a Massimo Risi:

Os seus chefes estão lá fora, não é? Pois os meus estão ainda mais fora. Está compreender? Viver é fácil: até os mortos conseguem. Mas a vida é um peso que precisa ser carregado por todos os viventes. A vida, caro senhor, a vida é um beijo doce em boca amarga. Entende, o senhor? (Ibidem, 157; sublinhado meu)

Porque:

O tempo aqui é de sobrevivências. Não é como lá, na sua terra. Aqui só chega ao futuro quem vive devagarzito. Nos cansamos só a afastar os maus espiritos. (Ibidem, 157; sublinhado meu)

«Explodidos», os soldados se teriam resumido, por sinédoque, ao sexo «avulso e avultado» em que, deles sobrado, eles se resumiam afinal: esse seu «hífen carnal» (Ibidem, 31): pois «eles coitados, acreditavam ser donos de fronteiras, capazes de fabricar concórdias» (Ibidem, 12). Esse «hífen carnal» sobre o qual «O representante do governo central [...] 
metafisicou hipótese: aquilo, em plena estrada, era um órgão ou um organismo?» (Ibidem, 28; sublinhado meu)... Talvez um orga-nismo - sim... - mas a contra-exemplo de «uma vida que se prefere»: um exemplo de vida nua... Porque, como diria Lévinas, em «Paix et proximité»:

Cette histoire d'une paix, d'une liberté et d'un bien-être promis à partir d'une lumière qu'un savoir universel projetait sur le monde et sur la société humaine [...] cette histoire ne se reconnait pas dans ses millénaires de luttes fratricides, politiques et sanglantes, d'impérialisme, de mépris humain et d'exploitation, jusque dans notre siècle de guerres mondiales, des génocides, de l'holocauste, et du terrorrisme; du chômage et de la misère continue du Tiers monde. (LÉVINAS 1995, 137)

\section{Bibliografia}

BHABHA, Homi. The Location of Culture. New York: Routledge, 1994.

BENJAMIN, Walter. O Anjo da História. Lisboa: Assírio \& Alvim, 2010.

BENJAMIN, Walter. Linguagem, Tradução, Literatura. Lisboa: Assírio \& Alvim, 2015.

BLANCHOT, Maurice. La part du feu. Paris: Gallimard, 1949.

BRUGIONI, Helena. Representação, História(s) e Pós-colonialidade. Braga: Húmus, 2012.

COSTA, Alcindo et alii. Bíblia Sagrada. Lisboa: Difusora Bíblica, 1978.

COUTO, Mia. O Último Voo do Flamingo. Lisboa: Caminho, 2004.

COUTO, Mia. E se Obama fosse Africano? E outras interinvenções. Lisboa: Caminho, 2009.

DERRIDA, Jacques. Força de Lei. Porto: Campo das Letras, 2003.

GRAVES, Robert. Os Mitos Gregos - I. Lisboa: Dom Quixote, 1990.

LEITE, Ana Mafalda. Ensaios sobre Literaturas Africanas. Maputo: Alcance Editores, 2013.

LÉVINAS, Emmanuel. Altérité et transcendance. Paris: Fata Morgana, 1995.

MALLARMÉ, Stéphane. Vers et Prose: morceaux choisis. Paris: Perrin, 1893.

REIS, Ricardo. Odes. Lisboa: Ática, 1987.

ROTHWELL, Phillip. Leituras de Mia Couto: aspectos de um pós-modernismo moçambica-no. Lisboa: Almedina, 2015.

SECCO, Carmen Lucia Tindó. «Entre crimes, detectives e mistérios (Pepetela e Mia Couto - riso, melancolia e o desvendamento da história pela ficção)». Mulemba v. 3, no 5 (2011); disponível em https://revistas.ufrj.br/index.php/mulemba/issue/view/426/showToc 